\title{
Widespread Neogene volcanism on Central Kerguelen Plateau, Southern Indian Ocean
}

\author{
R. A. Duncan ${ }^{\mathrm{a}}$, T. J. Falloon ${ }^{\mathrm{b}, \mathrm{c}}$, P. G. Quilty, ${ }^{\mathrm{b}, \mathrm{c}}$, and M. F. Coffin ${ }^{\mathrm{b}, \mathrm{c}}$
}

${ }^{a}$ College of Earth, Ocean, and Atmospheric Sciences, Oregon State University, Corvallis OR 97333 USA

${ }^{\mathrm{b} S c h o o l ~ o f ~ P h y s i c a l ~ S c i e n c e s, ~ U n i v e r s i t y ~ o f ~ T a s m a n i a, ~ H o b a r t ~} 7001$ Australia

'Institute for Marine and Antarctic Studies, University of Tasmania, Hobart 7001 Australia emailrduncan@coas.oregonstate.edu

\section{SUPPLEMENTARY PAPERS}

Australian Journal of Earth Sciences (2016) 63,

http://dx.doi.org/10.1080/08120099.2016.1221857

Copies of Supplementary Papers may be obtained from the Geological Society of Australia's website (www.gsa.org.au), the Australian Journal of Earth Sciences website (www.ajes.com.au) or from the National Library of Australia's Pandora archive (http://nla.gov.au/nla.arc-25194).

\section{SUPPLEMENTARY PAPER}

Electronic Annex A. Complete ArArCALC data files for ${ }^{40} \mathrm{Ar}-{ }^{39} \mathrm{Ar}$ incremental heating experiments on dredged rocks from Central Kerguelen Plateau. 